Treasury welcomed the proposal for more froquent transfers of scientists to the Administrativo Class, Mr. MacDermot thought that the reluctance of young scientists to take administrative posts was a practical difficulty and Britæin should perhaps sook to encourage those with the necessary aptitude to move into the Administrative Class at a lator rather than an earlier stago in their carcor. Movement in the reverse direction was exceedingly difficult. Encouraging results had been obtained in a trial transfer of thirtcen scientists to the principal grade of the Administrative Class. On exchanges between the Civil Service and industry, he said that more than 100 exchanges in the professional Administrative and Scientific Classes for short periods between the Civil Service and the private sector and nationalized industry had occurred in 1961- 63 . Opportunities for interchange of ideas and experience wero to be found at the Contro for Administrative Studies and in many management and similar courses elsewhere. The Government wishod to increase these opportunities. The question of a Civil Service staff college would bo further examined in relation to the long-term future of the Centre for Administrative Studies, where assistant principals now attended a three-week course on the structure of Government within the first six months of entering the Service. They attended a full 20-week course in their third year of service, doaling with economics, statistics, mathematical and other new techniques of administration. It was hoped that this year twenty members of the principal grade would take a six-week course in economies; an induction course for the professional, scientific and technical classes was being considered. On computers, he said there wore now 41 installed computers, 10 on order and possiblo requirement for 42 by 1970 .

\title{
DEVELOPMENT OF INVENTIONS BILL
}

$\mathrm{T}$ HE Devolopment of Inventions Bill, which reccived an unopposed second roading in the House of Commons on February 18, amends the Development of Inventions Acts of 1948-54, which establishod the National Research Development Corporation for securing the development and exploitation of inventions where roquirod by tho public interest. Under tho 1948 Act, the Board of Trade was empoworod to advance capital to the Corporation, and all the functions of the Board under these Acts have now been transferred to the Ministry of Technology by the Ministry of Technology Order, 1965. In moving the sccond reading, the Minister of Technology, Mr. F. Cousins, said that the previous Government had already announced on July 28 that it proposed to seek powers to extend the scope and scale of the work of the Corporation so that it would bo able to contribute more effectively to industrial innovation and developmont, particularly development in which industry shared the risk. That was the essential element of the Bill before the Houso, and it also included the proposal of the previous Government to raise the Corporation's present limit of borrowing power to $£ 25$ million. The Government also agreed that legislation should provide for a modification and extension of the financial and other conditions under which the Corporation operated, so that in partnership with industry it would have greater freedom to promote the development and commercial application of new techniques. The present Bill was built on these proposals, but the Government intended to make a slightly wider use of the powers of the National Research Devolopment Corporation. As to the purposes of the Corporation, $\mathrm{Mr}$. Cousing commented that by 1954 it had been realized that research to assist in tho dovelopment or exploitation of an invention was a necessary part of the Corporation's role, but that it had now become clear that further action was required. Essentially tho Corporation's work could be classified under three heads. First, the patenting and licensing to industry of inventions which wore already capable of practical application; secondly, assisting the development of inventions; thirdly, assisting research likely to lead to newer developments. For somo time past the second role had been assuming groater importance, and it was hero that major expansion was anticipated in futurc. So far research had not resulted in as much return as exploitation, or as much oxponditure as development, but had covered some important projects, and it was now clear that a longer period was oxpocted than had been originally envisaged beforo a return could bc obtained on research and dovelopment expenditure. The average period was now estimated to be about eight years. So far the Corporation had received about $£ 2$ million in royalty revenue, and, out of the $£ 6$ million which had been invested in development, about $\AA_{1} .4$ million had been recovered. Mr. Cousins also stressed the importance of co-operation between the Corporation and the Atomic Enorgy Authority, and said that Mr. Duckworth, the managing director of the Corporation, had accepted his invitation to serve on the Authority.

Turning to the Bill itself, Mr. Cousins said that Clauso 1 increased the capital at the disposal of the Corporation from $£ 10$ million to $\$ 25$ million and the time limit on its use had been removed. Certain alterations were also made in the accounting and in reporting the Corporation's activities under this Clause. Under Clause 2, if the Corporation had to write off a development project, wholly or in part, it could ask the Minister for a direction that it would no longer be liable to repay a corresponding sum from advances made to it. This Clauso also provides that any amount so writton off should still count against the $\$ 25$ million limit. Under Clause 3, the Minister could relieve the Corporation of the burden of interest for the first eight years of any advance, corrosponding with the average maturity period of a development project. Clause 4 extended the scope of the Corporation's activities, enabling Government departments, with the exception of the Post Office, which already had power to do so, to ask the Corporation to undertake projects at the expense of their own votes, and to pay the Corporation a management fee for doing so. This Clause provided that the Minister of Technology must approve the arrangement, and gave the Corporation the option of declining to take on projects proposed by Government departments. It was considered that the Minister must retain a general oversight of the Corporation's operations to prevent it from being overloadod, and that the Corporation must have the right to decline to carry out a particular project, bccause there might be incompatibility between such a project and the obligations that the Corporation had already accopted. Clause 6 enables the Minister to increase the mombership of the Corporation from 10 to 12 , and made it clear that the Corporation's duty under the Acts to balance its accounts was not to be taken as preventing it from so exercising its functions as to make a surplus on revenue accounts. In replying on the debate for the Government, the Minister of State for the Board of Trade, Mr. G. Darling, made no comment on the point raised by Mr. Marples concerning the future of the Joint Development Committee set up between the Corporation and tho Department of Scientific and Industrial Research. 